\title{
Ssciendo
}

Ethics \& Bioethics (in Central Europe), 2021, 11 (3-4), 196-205

DOI:10.2478/ebce-2021-0014

\section{Pandemic challenges and models of democracy}

\author{
Leszek Koczanowicz ${ }^{1}$
}

\begin{abstract}
This article examines the impact of a pandemic on democratic societies. The central research question is the extent to which a pandemic can alter the trajectory of social and ethical democratic development nationally and internationally. Therefore, the article examines contemporary controversies in democratic society in the aftermath of a pandemic. The leading hypothesis is that the pandemic should reinforce the need for social solidarity, but it is unclear what political form this need will take: populism or deliberative/nonconsensual democracy.
\end{abstract}

Keywords: pandemic, democracy, ethics of democracy, populism, deliberative democracy

\section{Pandemic and politics}

For a year now, the world has struggled with the rising tide of infections caused by SARSCov2. The scale of the problem is best illustrated by numbers: on the $25^{\text {th }}$ of November 2020 , a cumulative count of 62153458 confirmed cases was registered with a death toll of 1443300 , and on that day, there were 486545 confirmed cases and 6907 deaths (JHU, 30 Nov 2020). At the same time, however, it is stressed that not all countries have been equally severely affected by the pandemic. According to data provided by John Hopkins University Coronavirus Resource Centre, the highest death tolls have been registered in the US, Brazil, India, Mexico, and the UK (JHU, 30 Nov 2020).

These shocking statistics revealing the scale of the problem indicate that the pandemic is not only a matter of purely technical actions of the healthcare system and medical services, although, admittedly, it is now extremely important to assess their operation, but above all, it is a social, political, and cultural phenomenon which, evidently, can have far-reaching effects on societies. The great Black Death epidemic that decimated the population of Europe in the $14^{\text {th }}$ century affected the economy of that period, and indirectly, its politics. Historical data show that although during the plague social inequalities in terms of income decreased, the situation swiftly came back to the norm and even increased (Scheidel, 2018). Evidently, the plague, enhanced and accelerated pre-existing tendencies rather than created new social or political mechanisms. The COVID-19 pandemic, however, shows specific traits whose political impact should be analyzed before we can assess its far-reaching consequences.

The pandemic exposes both the weaknesses and strengths of science. In this respect, it is "scientifically" constructed. Without access to pandemic statistics and mathematical propagation equations, it could have been easily overlooked or taken for a new strand of flu. Nevertheless, the influence of these indicators can be deemed ambivalent. Warnings were often ignored or lost in the information overload, as they referred to previous epidemics which, despite initial concerns, were limited in scope. This led to the underestimation of the threat at the onset of the virus before scientific research provided adequate data and, first of all, proper extrapolations which forced governments to take suitable action. The power of science was sufficient to construct the pandemic, but insufficient to contain it. Sophisticated methods of science, such as genetic tests, biochemical analyses on the one hand, and elaborate techniques of mathematical modelling on the other, are harnessed to implement the most basic and timetested methods, such as quarantine and isolation. Obviously, these ancient measures are complemented with state-of-the-art methods of social modelling, but they have been unaltered

\footnotetext{
${ }^{1}$ SWPS University of Social Sciences and Humanities (Poland); 1koczanowicz@swps.edu.pl; ORCID: 00000002-4204-1674
} 
at their core and their application is basically intuitive as is shown by the differences in scope and strictness of the implemented measures in particular countries. We are thus presented with a paradox here. In many cases, the effects of the pandemic are not clearly visible in "the world of everyday experience" (Lebenswelt); they appear as dry numbers of new cases in media reports. Simultaneously, epidemiologic data and modelling methods based on elaborate statistics show that we are confronted with a lethal threat.

This specific nature of the pandemic obviously affects its reception in everyday life due to the fact that its visibility is limited, or, so to speak, secondary. What most of us can see are empty streets and precautionary measures such as face masks, disinfectants, protective gloves, social distancing, etc. We see much more through the media: the pandemic is probably the first health crisis that is so widely, globally broadcast and discussed in real time. The discordancy between the direct perception of the pandemic and the necessary- as scientists and governments insist on restrictions changing everyday life - brings about a constant tension which has not yet been alleviated in any pandemic-stricken countries. Due to this discrepancy, a cognitive gap is created through which all sorts of fantasies squeeze in, starting from conspiracy theories, through dusted-off religious preaching of the penalty for sins and related millenarism, to visions of the new world emerging after the pandemic has been eradicated.

\section{Ethics of democracy}

In this paper, I understand democracy not as a set of institutions, rules, and procedures but more as a form of life, to use Wittgenstein's category: "So you are saying that human agreement decides what is true and what is false?' - It is what human beings say that is true and false; and they agree in the language they use, That is not agreement in opinions but in form of life" (Wittgenstein, 1999, §241). For this reason, the most important thing for the functioning of democracy is the ethical engagement of citizens, which grows out of the form of political life and at the same time constitutes this form.

In political philosophy this ethical concept of democracy can be illustrated by two apparently different traditions. The first tradition is of French political philosophy where I see a special place for the works of Claude Lefort. The second is that of American pragmatism, especially John Dewey's concept of democracy. I think that what is also common for them is the concept of the dynamic of the democratic system. They believe that democracy doesn't necessarily mean consensus but on the other hand they do not think that any antagonism has to lead to rejection of liberal democracy. As Claude Lefort states, if we are aware of these setbacks of democracy then we can protect it from the temptations of totalitarianism. Democracy is a system of constant internal struggle because it differs from other political forms in that that it is organized around "empty space". As an expert on Lefort writes:

[W] ithin a democracy, the source of legitimate power is 'the people' but who is to speak in the name of people? According to Lefort, political life on modern democracy is a continual debate on just this question. No-one claim can to be authorized a priori to speak in the people's name; each person's claim must be discursively validated and every claim is always subject to challenge. The legitimate spokeperson for the people cannot be established with certainty; it is always 'up for grabs' and as such it engenders an anxiety. The political anxiety which is endemic to democracy is experienced most intensely in times of crisis; it has its 'object' the possibility that the symbolically empty space will become really empty, which is to say, no one will be able to establish legitimacy and this would mean that the symbolic place of power would fall into [the] real (Flynn, 2005, pp. xxv-xxvi).

Thus, the struggle to legitimize the definition of "the people" is built into the system. Antagonism is thus the essence of democracy, and at the same time a threat to democratic society 
and a source of its strength. Democracy must constantly define itself and is a system that requires constant change. On the other hand, it is also in constant danger of falling into totalitarianism, where the empty space is filled by a clear definition of "the people". The moral for democratic theory is that since the threat of totalitarianism is endemic to democracy, the only way to protect that system is for the people to actively participate in its defense. However, one must think of democracy not in terms of a system or institution, but in terms of habits and moral commitment. Democracy is from this point of view both an ideal and a form of life.

For Dewey, democracy is a kind of inquiry that is directed toward facilitating the social life of the individual. "[...] organization is never an end in itself. It is a means of promoting association of multiplying effective points of contact between persons, directing their intercourse into the modes of greatest fruitfulness" (Dewey, 1950, pp. 160-161). This assumes, of course, that Dewey accepts at least a weak version of the social ideal of democracy. This ideal can be understood precisely as an idea that guides or regulates the development of society and the individual. The individual may, of course, enjoy more or less freedom in a given society, depending on historical conditions, but this does not mean that progress is impossible. It is measured by the development of all the abilities of the individual through an appropriate relationship with others.

Democracy is thus a system that operates in constant ethical tension, this tension can be represented in the form of a triangle: ideals (values) - action (customs, practices of democracy)

- institutions. Relating to each side of this triangle requires ethical sensitivity and a critical relationship to ideals, practices, and institutions. Ideals challenge democracy as a promise that, even if impossible to fulfill, must be activated and reactivated so that the practice of democracy does not fall into a daily routine of small institutional actions that cannot be translated into a broader perspective.

The practice must, in turn, create a conscious context for engaging in democracy and defending its principles against the anomie of legitimacy and the totalitarianism that emerges from this anomie, against the temptation to replace democratic heterogeneity with the totalitarian unity of "the people". The institutional dimension of democracy must be constantly challenged in the sense that democracy, in order to survive, requires the coexistence of competing social and political projects. It is therefore crucial and vital for democracies to be imaginative and creative in their design. The pandemic is a challenge to democratic politics and, at the same time, a test of the efficiency of a democracy that can survive even the worst conditions. Because the pandemic involves not only institutions but also people's daily lives, it must reconfigure the democratic triangle I mentioned above.

\section{The Pandemic and the controversies of democratic society}

The specific nature of the current pandemic and the entirety of experience gained while responding to this crisis may significantly change the form of democratic societies. It is noteworthy that the pandemic has set off certain contradictory tendencies and, at present, it is difficult to predict the drift of events. Moreover, similarly to the previous great plagues, the COVID-19 pandemic is a sort of an amplifier of preexisting social and political trends. It can be assumed that some trends will be enhanced while others will be rejected or reduced. Let me point to some of the major areas in which such trends may occur or have already occurred.

One such area is undoubtedly globalization and, to be more precise, the question is whether the effect of dealing with the pandemic will be to strengthen international cooperation or whether the opposite trend towards national autonomy will prevail.

The pandemic is a global phenomenon and thus it should be dealt with globally. It is reflected at numerous levels. Chinese scientists, by making the virus genome accessible, helped accelerate timelines for development and rolling out new vaccines. Sharing information on the virus altered the trajectories of scientific publications and helped create platforms for instant, 
cost-free sharing of findings. International cooperation is essential for development, allocation, and deployment of new vaccines. Similarly, close cooperation is required to alleviate the economic losses caused by the pandemic. A clear example is the EU's initiative to set up a fund for the compensation of economic losses incurred due to the pandemic.

At the same time, as is generally known, the governments of Poland and Hungary highlight the sovereignty and autonomy of the national state. Although their attitude is evidently related to certain internal policy issues, nevertheless it signifies a deeper problem. The pandemic, while enforcing cooperation, at the same time strengthens the sentiments for an autonomous national state. The pandemic response has never been agreed upon by states, on the contrary, each country implemented their own strategy. Obviously, these strategies showed some common elements, but they were the result of common conditions rather than the consequence of intentional cooperation. Moreover, the national strategies of pandemic response seem to reflect the political system and culture of a given country rather than general pandemic factors. A comparison between China and Sweden provides a clear illustration of this characteristic. The former resorted to radical control of citizens' behavior while the latter implemented appeals and democratic debates on applied restrictions. The separatist trends in national states may also be reinforced by so called "vaccine nationalism" i.e., the efforts of particular countries to acquire and distribute the vaccines as quickly as possible. This attitude seems understandable as the effectiveness shown in such an important area can, to a large extent, translate into favorable results in the post-pandemic-elections. This strategy is not only instrumental in character; the national divisions into 'us' and 'them' still play a key role as governments try to fight for their "own" citizens. Such an attitude, however, leads to enhanced entrenchment in nationalist positions.

In this case the pandemic enhances the preexisting controversy between tendencies to form supranational institutions and organizations and to return to the well-known forms and institutions of national state. It should be assumed that the COVID-19 epidemic favors the latter trend, at least in the sense that the state is more trusted than distant, transnational forms of power. This is due to the fact that, according to the laws of social psychology and sociology, in crisis situations there is a tendency to close in well-known cognitive structures. There is also a tendency to simplify the situation to find quick solutions So, it seems that, at least in the near future, democratic forces will come under pressure from supporters of a return to the greatest possible powers of the national state and extreme isolationism. It is a dangerous trend because even the eradication of this pandemic will not safeguard us against new strains which may threaten the world. According to many scholars, our ways of producing food, but also social habits will promote the propagation and spread of new strains of the virus. Such a new strain has already appeared in the UK during the holiday week. Fortunately, it seems that newly developed vaccines will also be effective in this case, but worse case scenarios cannot be ruled out in the future. Moreover, other global challenges, such as climate issues, which require the cooperation of many countries, have not disappeared.

\section{Democracy of expertise or democracy of sovereignty: the media and "fake news"}

The pandemic is an extremely complex phenomenon whose understanding, as I wrote above, requires considerable scientific knowledge as well as knowledge how to combat it. Pandemic decisions are made by politicians on the basis of the expertise of scholars or, strictly speaking, are often a compromise between policy requirements and science-based guidelines. For example, when epidemiologists recommend a strict closure and politicians choose a softer variant for the sake of economy or to adjust it to citizens' habits. Despite such compromises, the authority of experts has become significant. Scientists often endorse decisions and take responsibility for them. Thus, the pandemic enhances tendencies whose origins can be traced back to the beginnings of liberal democracy and which have been on the increase since the 
beginning of the $19^{\text {th }}$ century - leaving key decisions in the hands of experts. It is not surprising as modern societies are complex organisms whose functioning depends on the cooperation of many elements. To be able to see these interdependences requires knowledge which is, obviously, not equally accessible to everyone, hence the role of experts. However, this knowledge has been contested and questioned as often as it was used. A great debate on the role of experts swept through all the countries affected by the 2007-2009 financial crisis when economy professionals took up the reins of power and dictated the measures for alleviating the crisis. An additional issue is the erosion of trust in science caused by the fact that expert opinions are often deemed contradictory and inconclusive, which leads to all kinds of disinformation taking the form of "fake news", especially widespread on social media. Therefore, even if we were to assume, following the early $20^{\text {th }}$ century pioneer of media science, Walter Lippman, that expert authority is a necessity, its rationality would still be threatened by information overload on social media. Unfortunately, the pandemic has enhanced a tendency to undermine the role of scientific experts, even though surveys show that $61 \%$ of Poles still trusts scientists and the healthcare system the most, only $21 \%$ trusts the government and $26 / \%$ trusts the media (Wróblewski, Meler \& Afeltowicz, 2020). The pandemic has become a testing ground for spreading chaos and information hype into social media (Anwar, Malik, Raees et al., 2020).

The opposite of expert democracy is popular sovereignty democracy where the voice of the majority is decisive in all matters. This concept is generally referred to by populist movements whose ideologists claim that most decisions are made by experts or court verdicts based, after all, on expert opinions. Resisting such a state of affairs is, according to many experts, one of the mechanisms which fuels populism. It coincides with the difficulty experienced by a growing number of people, to understand complex rules and procedures governing modern, democratic society. As noted by the prominent political psychologist, Shawn Rosenberg, liberal democracy has fallen victim to its own success. People's cognitive powers are not developed enough to cope with the complexity of democratic politics (Rosenberg, 2021). If his diagnosis is correct, the challenges facing democracy are not incidental, but they lie at the core of its functioning. Undoubtedly, if we adopt this perspective, the pandemic may be instrumental in the failure of liberal democracy system. The reason is obvious, further restrictions and regulations, in many cases incomprehensible to most people, increase the complexity of the system. The justifications for implementing new rules are convoluted and the procedures themselves are often ambiguous. Therefore, it is not surprising, that in many countries, there are trends which oppose such conjuncture. They are generally politically marginal, but it seems reasonable to presume that they will leave their mark on people's mentality, evoke mistrust in democracy and shift public sentiment toward populism. An additional effect may be a growing distrust in science which manifests in COVID-19 vaccination resistance.

The pandemic, even when it is over, will make its mark on democratic societies. It may significantly reduce trust in science, and, consequently, reduce the level of rationality in political debates and decisions. Obviously, politics is never fully rational, but a "healthy" democratic policy requires a certain balance between a scientific approach to social issues, and emotions. The pandemic has undermined this balance and, as a consequence, the increase of populist sentiment may take place. It can be reduced, to some extent, by a rapid economic recovery, but it seems unlikely that simply improving the economy will be sufficient. There is a need to restore trust in science which must, however, be achieved by incorporating scientific data into social discourse. This strategy is necessary, not only in post-pandemic situations but also because of other global challenges facing humanity. If we fail to persuade the general public to the rational response to such an immediate threat as the pandemic, it will be even more difficult to convince them of proper action in response to climate change which also requires change in deep-rooted habits and reduction of consumption. It is, therefore, necessary 
to consider the implementation of policy that would allow for an open debate on expertproposed solutions. However, this, in turn, requires clearing the forefront of incorrect information and fake news. The EU-adopted directive of the $3^{\text {rd }}$ of December 2020 "On the European democracy action plan" (The Commission, 2020) gives clear guidelines on how to proceed in case of disinformation generated by both domestic organizations which contest the state policy, such as the anti-vaccine movement and by foreign powers which are interested in weakening democratic states in the EU. Implementation of the directive is a necessary step in the process of incorporation of science into democratic discourse.

\section{The pandemic and the models of democratic societies}

The consequences of the pandemic have a significant influence on the present-day debate on democracy. This impact can be considered in two aspects:

Firstly, the lessons learned from the pandemic make it possible to predict the paths of development of different models of a democratic society, at least in the sense that we now know that certain opportunities have been blocked for a long time. As I wrote above, after the end of the Black Death in the $14^{\text {th }}$ century, the inequalities that had been eliminated for a moment returned with renewed strength.

In any case, the prevalence of communal thinking can be expected in the near future. The plague brought a significant change in this respect, namely, in the dispute between communitarians and liberals, it has tipped the balance in favor of the first option. During the pandemic, people seek to identify with a group, a community, and the obvious choice for such identification is nation and/or religion. This identification may be superficial to a large extent, since a community which is thus created is, first of all, a community of suffering, but political ideologies translate it into accessible, easily articulated values, such as the nation or a particular religion.

Community involvement also entails a particular paradox. The sense of belonging to a community is combined with behaviors of individualistic character. People in isolation are alienated individuals who are, in a way, connected by restrictions imposed by law. Therefore, it can be said that they are a paradigmatic example of the most fundamentalist liberal theory. However, the situation is at least partially broken by the use of new media, especially, social media. All in all, it can be said that the mechanism driving communal thinking is fear, both of the pandemic and of its economic and social consequences. The vast majority of people in closure-affected countries realize that only joint effort can mitigate the impact of the pandemic.

On a political level, the intensified sense of belonging to communities can manifest in a number of ways, which fall under various parts of the political spectrum. On an economic level, it is certain that massive state intervention in the economy will be unavoidable. It seems that extremely popular, neoliberal, economic recipes have lost their power. David Harvey points out that the pandemic even forces capitalist economy to adopt more pro-social solutions.

It applies specifically to the sphere of distribution and redistribution of goods (Harvey, 2020). At present, it is difficult to imagine radical free-market capitalism with minimal state intervention. The pandemic can therefore have similar effects to those which WWII had on the European economy when the war experience gave rise to the welfare state. It was founded on a public consensus to alleviate the inequalities through transfers from the wealthy to the lower earners (Piketty, 2014). Undoubtedly, evident neglect in the public sectors, especially in healthcare which came to light during the pandemic, will have to be more than compensated. Biopolitics will combine with social policy. Public healthcare has to be connected with actions aiming at equalizing opportunities and alleviating inequalities. The consequence of the pandemic should therefore be favoring solidarity solutions, at least in terms of the economy. Nevertheless, this is only the first step in the analysis of the effect of the pandemic on democratic models. Each of the models below is, at its core, a certain spectrum of possible 
political solutions, and as such, has to be analyzed separately. Moreover, solidarity/social solutions in an economy can involve entirely different political strategies, ranging from authoritarianism to dialogue.

Secondly, an important aspect is the internal analysis of various models of democratic society. For the sake of analysis, I chose the following options: (1) representative parliamentary democracy (classic liberal model of democracy), (2) populism, (3) deliberative democracy, (4) hegemonic model of democracy, (5) non-consensual democracy, whose outline I presented in my book (Koczanowicz, 2016).

Representative parliamentary democracy (classic democracy model) has been in permanent crisis for many years now, which has been repeatedly diagnosed and described (Mounk, 2018; Zielonka, 2017). The fundamental problem in this model is its hybrid character; it is a combination of two separate projects: inalienable individual rights (human rights) and majority rule. Both parts were consonant with each other for nearly 200 years, though obviously not without some friction. However, in the last two decades, there has been a distinct imbalance between them. The common point is that key decisions affecting people's lives are made by courts or experts and implemented through complicated and incomprehensible procedures. In public perception, the most important issues and decisions that affect people's lives are made behind people's backs although they should be the subjects of democracy. The course of the pandemic so far indicates that the situation of liberal democracy has declined. Although, according to Freedom House reports, authoritarian regimes are restricting human rights during the pandemic the most, democratic countries also have troubles with realizing the fundamental principles of the democratic system. In 88 countries, a partial retreat from democratic rules can be observed (Repucci \& Slipowitz, 2020). Obviously, the question to what degree will these negative changes affect democracy remains open, but it can be expected that liberal democracy will be weakened in many countries. ${ }^{2}$

Populism is currently the main adversary of liberal democracy. Numerous studies give various definitions of it, but distrust of the ruling elites and the tendency to introduce clear "us" versus "them" divisions come to the fore (Mudde \& Kaltwasser, 2017). The second characteristic of populism may be the term "non-liberal" democracy", because out of the two pillars of liberal democracy I mentioned above, populism, at least declaratively, would like to leave just one, i.e., direct rule of the people (Zakaria, 2003). This strategy is closely related to an anti-elitist attitude; populist movements seek to present themselves as the" vox populi", stigmatizing elites for being out of touch with social realities. In the majority of the literature on populism, it is widely debated whether such a general attitude can turn into a specific political agenda, all the more so because the program spectrum of populism is extremely broad.

The issue becomes pressing when groups which preach such slogans (voice of the people, anti-elitism) come to power either alone or as part of a governing coalition, as in the case of Poland and Hungary. Current experience shows that such system shows a tendency to strengthen executive power at the expense of other elements of the democratic system, which may be a prelude to authoritarianism. Anti-elitist and anti-procedural attitudes of populism predispose it to take a skeptical or even hostile stance on anti-COVID-19 measures. Cultural populism is coupled with anti-vaccination and, generally, anti-medical movements. However, political analyses indicate that political populism is rather cautious in this matter. A report by the Tony Blair Institute for Social Change found that out of the 19 populist leaders analyzed, only 5 were skeptical about the pandemic (Meyer, 2020). This is probably due to the fear of losing support in the face of the noticeable effects of a healthcare crisis. ${ }^{3}$ Nevertheless, it seems

\footnotetext{
${ }^{2}$ This is what $65 \%$ of experts surveyed in the study cited above expect. Poland is quoted as a country where: "Politicians make a statement unsupported by facts".

${ }^{3}$ It can be assumed that Donald Trump's ambivalent attitude towards the pandemic contributed to his election defeat (cf. Paz, 2020).
} 
obvious that populist or quasi-populist countries (Hungary, Poland, the US during the Trump era, and the UK during Boris Johnson's rule) have regarded the pandemic as a useful tool in the political game, highlighting the threat at times when it brings tangible political benefits. A key moment in the discussions on democracy will certainly be the introduction of vaccines and the convincing of people to get vaccinated. If this means the end of the pandemic, liberal democracy, with its attitude towards rational discussion, should be strengthened. However, when the whole operation fails and the pandemic continues to be a threat, it will fuel populism. An additional problem is the anticipated economic crisis resulting from the pandemic. It is clear that it will fuel the popularity of populist movements unless it is relatively quickly reduced through extensive state intervention.

Alternative models of democracy include deliberative, hegemonic, non-consensual and it is known that the problems of liberal democracy were already noticed in the late 1970s and 1980s and then certain models of democracy appeared that were supposed to be improvements of the classic model. I am thinking here about deliberative democracy and hegemonic (radical) democracy. These two models come from different premises. In the case of deliberative democracy, they were the concepts by J. Habermas and J. Rawls who claimed that a rational consensus can always be achieved provided that certain political requirements are met. Improving democracy would mean that democratic debate cannot be reduced to just making choices from a specific pool of proposals put forward by the parties, but it must take so long that the various positions and arguments behind them can be presented. Then the choice will be truly conscious and rational. Hegemonic democracy, on the other hand, assumes that conflict is an inevitable feature of a democratic society and, as such, should not be avoided but rather "tamed" through turning opponents into adversaries, and antagonism into agonism. Then, the democratic vote gives hegemony to the winning side, but at the same time, the losing side can work on a rematch in the next election. The concept of non-consensual democracy emphasizes understanding which is supposed to be the middle way between the above-mentioned concepts. According to it, the aim of democratic dialogue is, first and foremost, to understand, not to agree. Deliberation, even if it does not lead to the consensus, paves the way to better mutual understanding among the sides of a conflict. I am discussing these three concepts together despite their significant differences, as they largely remain experiments of some kind, although they take on a new meaning in the face of popular belief that the classic model of liberal democracy needs to be changed.

Actually, finding ways to improve the classic model is now a matter of survival of democratic society. A report by the Bennet Institute for Foreign Policy, and the Cambridge University based on surveys of nearly 5 million respondents from 160 countries between 1973 and 2019, shows a disturbing, but ambiguous trend. In general, every subsequent generation, starting with the first post-war generation, has become increasingly disillusioned with democracy. The "millennials" are the most disillusioned with democracy of all generations. However, the report's authors observed an interesting phenomenon; in countries where populist leaders (both left and right) came to power, young people's support for democracy increased. Nevertheless, conclude the authors, it is uncertain what will happen if populists are in power for longer than one term. There are reasons to believe that then the support for democracy may diminish (Foa, Klassen, Wenger et al., 2020).

Everything that has been said above indicates that, to a large extent, the future of the democratic system will depend on how national authorities, but also transnational organizations (the European Union is an obvious example here) can cope with the pandemic. The question is not only whether they will be able to effectively eradicate the epidemic, but also what means they will use and, above all, to what extent they will be authoritarian decisions, and to what extent they will have wider public support. It is certain that the pandemic will accelerate the transformation of classic, liberal democracy. It must be enriched with elements of social 
solidarity at an economic level and should possess greater co-decision possibilities. This should foster deliberative or participatory democracy, although it can be assumed that new forms of communication and political decisions can be established using new social media. If it is defeated in the fight for public support and fundamental decisions are made authoritatively, the populist movement, which contains elements of the hegemonic concept of democracy, but without its most important part, namely allowing all social voices into discourse, will gain the upper hand. Social media will then serve to build an information monopoly.

\section{Final conclusions}

The pandemic is a multi-aspect phenomenon of medical, social, cultural, ethical as well as political dimensions. Politically, it acts as a catalyst of certain trends that existed prior to its occurrence. It strengthens certain tendencies while reducing others. At present, during the pandemic, we can identify the areas where its impact is most significant, but, on the whole, we are not yet able to determine the direction of this impact. However, it is now clear that, as a consequence of the pandemic, political and ethical ideas that promote social solidarity will come to the fore, at least in the sphere of distribution. The pandemic has therefore enhanced a current of ethical criticism of the free-market capitalism (neoliberalism), already existing in the public sphere, together with its political and legal superstructure. It is not clear, however, what political solutions will emerge as the consequences of this critique. (Re)distributive actions may be based on a broad public discourse, but they may also be arbitrary actions by governments strengthening their authority.

The pandemic is one of many global crises, and similar threats may occur in the future. The settled, authoritarian response patterns to these issues, and the belief that they are the only way to resolve them will pose a serious threat to the survival of democratic societies.

The pandemic has clearly demonstrated that democracy must be radically reformed in order to survive such crises. The reforms should aim at increasing the scope of participation and deliberation, also through the use of social media. In the long run, transparent mechanisms need to be put in place for the relations between science (experts) and policy decision-making, which, combined with information policy, should reduce the effects of disinformation in the media, especially social media. Political education is absolutely crucial to ensure universal participation in decision-making as it guarantees better understanding of democratic procedures.

\section{Acknowledgement}

The research on this paper has been supported by the EU Horizon 2020 grant EUARENAS nr 959420

\section{References}

ANWAR A., MALIK M., RAEES, V. et al. (2020): Role of mass media and public health communications in the COVID-19 pandemic. In: Cureus, 12(9). [online] [Retrieved December 10, 2020] Available at: https://www.cureus.com/articles/38293-role-of-mass-media-andpublic-health-communications-in-the-covid-19-pandemic

COUNCIL (THE), THE EUROPEAN ECONOMIC AND SOCIAL COMMITTEE AND THE COMMITTEE OF THE REGIONS (2020): On the European democracy action plan. December 2, 2020 [online] [Retrieved December 10, 2020] Available at: https://ec.europa.eu/commission/presscorner/detail/en/ip_20_2250

DEWEY, J. (1950): Reconstruction in philosophy. New York: New American Library. FOA, R. S., KLASSEN, A., WENGER, D., RAND, A. et al. (2020): Youth and satisfaction with democracy: Reversing the democratic disconnect? Cambridge: Bennett Institute for Public Policy. 
FLYNN, B. (2005): The philosophy of Claude Lefort. Evaston, IL: Northwestern University Press.

HARVEY, D. (2020): Anti-capitalist politics in the time of COVID-19. In: Jacobin, [online] [Retrieved December 16, 2020] Available at: https:/jacobinmag.com/2020/03/david-harveycoronavirus-political-economy-disruptions

JOHN HOPKINS UNIVERSITY CENTER FOR SYSTEM SCIENCE AND ENGINEERING (JHU CSSE) (2020): [online] [Retrieved 30 November 2020] available at: https://coronavirus.jhu.edu/

KOCZANOWICZ, L. (2016): Politics of dialogue: Non-consensual democracy and critical community. Edinburgh: Edinburgh University Press.

MEYER, B. (2020): Pandemic populism: An analysis of populist leaders' responses to Covid19. In: Tony Blair Institute for global change, [online] [Retrieved on December 12 2020] Available at: https://institute.global/policy/pandemic-populism-analysis-populist-leadersresponses-covid-19.

MOUNK, Y. (2018): The people vs. democracy: Why our freedom is in danger and how to save it. Cambridge, MA: Harvard University Press.

MUDDE, C. \& KALTWASSER, C. (2017): Populism: A very short introduction. Oxford: Oxford University Press.

PAZ, CH. (2020): All the president's lies about the coronavirus. In: The Atlantic, November 2 2020 [online] [Retrieved on December 12 2020] Available at: https://www.theatlantic.com/ politics/archive/2020/11/trumps-lies-about-coronavirus/608647/

PIKETTY, T. (2014): Capital in the twenty first century, trans. A. Goldhammer. Cambridge, MA: The Belknap Press of Harvard University Press.

REPUCCI, S. \& SLIPOWITZ, A. (2020): Democracy under lockdown: The impact of COVID19 on the global struggle for freedom. In: Freedom House, October 2020 [online] [Retrieved on December 15, 2020] Available at: https://freedomhouse.org/sites/default/files/202010/COVID-19_Special_Report_Final_.pdf

ROSENBERG, S. (2021). Democracy devouring itself: The rise of the incompetent citizen and the appeal of right wing populism. In: Psychology of Political and Everyday Extremism. UC Irvine, June, 28 [online] [Retrieved July 2, 2021] Available at: https://escholarship.org /uc/item/8806z01m

SCHEIDEL, W. (2018): The great leveler: Violence and the history of inequality from the stone age to the twenty-first century. Princeton: Princeton University Press.

WITTGENSTEIN, L. (1999): Philosophical investigations. Oxford: Blackwell.

WRÓBLEWSKI, M., MELER, A. \& AFELTOWICZ, Ł. (2020): Poles on pandemic [online] [Retrieved on December 12, 2020] Available at: https://www.researchgate.net/publication/ 34R6682800_Risk, Confidence,_Infectious diseases, Poles on pandemic

ZAKARIA, F. (2003): The Future of freedom: Illiberal democracy at home and abroad. New York London: W.W Norton.

ZIELONKA J. (2017): Counter-revolution: Liberal Europe in retreat. Oxford: Oxford University Press. 